\title{
METODE DESAIN ARSITEK DALAM MENDESAIN RUMAH TINGGAL
} STUDI OBJEK: RUMAH TINGGAL ARSITEK DI MALANG

\author{
Adhi Widyarthara \\ Dosen Prodi Arsitektur, Fak. Teknik Sipil dan Perencanaan, ITN Malang \\ e-mail: adhiwidyarthara@gmail.com \\ Hamka \\ Dosen Prodi Arsitektur, Fak. Teknik Sipil dan Perencanaan, ITN Malang \\ e-mail: hamka07@lecturer.itn.ac.id \\ Sri Winarni \\ Dosen Prodi Arsitektur, Fak. Teknik Sipil dan Perencanaan, ITN Malang \\ e-mail: sriwinarni@lecturer.itn.ac.id
}

\begin{abstract}
ABSTRAK
Dunia Pendidikan arsitektur mengajarkan berbagai macam jenis teori mengenai metode desain arsitektur rumah tinggal. Namun, teori-teori desain tersebut perlu diuji keberlanjutannya setelah keluar dari lingkungan akademik, apakah hal tersebut sepenuhnya diterapkan didunia praktisi, mengalami penyesuaian atau justru tidak dipakai sama sekali, sehingga objek penelitian yang tepat untuk mengkaji hal tersebut adalah arsitek dan rumah tinggalnya. Pengalaman-pengalaman desain yang didapatkan oleh para arsitek selama terlibat langsung dalam dunia kerja dan projek yang ditangani, tentunya membentuk sebuah pemikiran baru mengenai cara atau metode berarsitektur. Penelitian ini bertujuan untuk mengetahui metode berarsitektur arsitek di Kota Malang dalam mendesain rumah tinggal. Manfaat dari hasil penelitian dapat digunakan sebagai bahan ajar perancangan rumah tinggal bagi mahasiswa dan memberikan pengetahuan bagi masyarakat umum mengenai aspek-aspek yang perlu diperhatikan dalam rancang bangun rumah tinggal. Metode yang digunakan dalam penelitian ini, yaitu metode kualitatif, dengan teknik wawancara mendalam (deep interview) dan observasi lapangan dengan variable kajian penelitian, kemudian dianalisis melalui teori-teori berdasarkan variable-variabel yang telah ditentukan. Hasil dari analisis tersebut kemudian diuraikan kualitatif untuk mendapatkan sebuah kesimpulan akhir. Hasil penelitian menunjukkan bahwa terdapat pengelompokan cara berarsitektur (balckbox dan glassbox) masing-masing arsitek dalam mendesain rumah tinggalnya. Aspek desain yang menjadi faktor penting dalam mendesain juga berbeda-beda, semua tergantung pada konteks, keinginan dan kebutuhan dari masing-masing arsitek.
\end{abstract}

Kata kunci : Metode desain, arsitek, rumah tinggal 


\begin{abstract}
The architectural education teaches various types of theories regarding residential architecture design methods. However, the design theories need to be tested for sustainability after leaving the academic environment, whether they are fully applied in the practitioners' world, experiencing adjustments or not being used at all, so that the appropriate research objects to study these are the architect and his home. The design experiences gained by the architects during their direct involvement in the world of work and the projects being handled, certainly formed a new thought about the method or method of architecture. This study aims to determine the architectural method of architecture in the city of Malang in designing residential homes. The benefits of the research results can be used as teaching materials for the design of residential houses for students and provide knowledge to the general public about aspects that need to be considered in residential building design. The method used in this study, namely the qualitative method, with deep interview techniques and field observations with research study variables, then analyzed through theories based on predetermined variables. The results of the analysis are then described qualitatively to get a final conclusion. The results showed that there are groupings of architectural ways (balckbox and glassbox) of each architect in designing their homes. The design aspects that are important factors in designing also differ, all depending on the context, desires and needs of each architect.
\end{abstract}

\title{
Keywords : Design method, architect, house
}

\section{PENDAHULUAN}

Rumah tinggal atau hunian merupakan sebuah bangunan yang berfungsi sebagai tempat untuk menikmati kehidupan yang layak dan nyaman, tempat untuk berlindung, berkumpul, dan menunjukkan status tingkatan social dalam masyarakat. Dalam dunia akademik pendidikan arsitektur, mendesain sebuah bangunan diperlukan sebuah langkah-langkah proses merencanakan dan merancang untuk mencapai sebuah tujuan akhir. Demikian juga untuk mendapatkan sebuah hunian rumah tinggal yang layak dan nyaman untuk dihuni tentunya membutuhkan sebuah proses desain yang mempertimbangkan berbagai macam aspek. Metode desain dalam arsitektur telah diajarkan dalam dunia pendidikan arsitektur yang terdapat dalam berbagai macam teori-teori tentang bagaimana proses merancang sebuah objek arsitektur, terkait dengan tema-tema desain, aspek-aspek desain seperti tapak, ruang, tampilan, material, lingkungan, iklim, social-budaya, dan keinginan dari calon penghuni rumah itu sendiri. Aspek-aspek tersebut perlu didapatkan datadatanya dan diolah melalui proses observasi dan pengumpulan data, programing, analisis, konsep, hingga mencapai sebuah hasil desain.

Teori-teori desain yang diajarkan didunia pendidikan arsitektur perlu diuji keberlanjutannya setelah keluar dari lingkungan akademik, apakah hal

PAWON: Jurnal Arsitektur, Nomor -- Volume --, Bulan Tahun, ISSN 2597-7636 
tersebut sepenuhnya diterapkan didunia praktisi, apakah mengalami penyesuaian atau justru tidak dipakai sama sekali, sehingga subjek penelitian yang tepat untuk mengkaji hal tersebut adalah praktisi/arsitek itu sendiri. Pengalaman-pengalaman desain yang didapatkan oleh para arsitek selama terlibat langsung dalam dunia kerja dan projek yang ditangani, tentunya membentuk sebuah pemikiran baru dan mendapatkan cara atau metode berarsitekturnya sendiri-sendiri.

Penelitian mengenai metode desain arsitek dalam mendesain rumah tinggalnya sendiri ini bertujuan untuk mengetahui cara, karakter, atau tipologi metode berarsitektur arsitek-arsitek yang ada di Malang dalam mendesain rumah tinggalnya sendiri. Manfaat dari hasil penelitian dapat digunakan oleh mahasiswa dalam mendesain tugas perancangan rumah tinggal dan juga bagi masyarakat umum yang tidak mampu menggunakan jasa seorang arsitek untuk mendapatkan desain hunian yang layak, aman, dan nyaman sesuai dengan keinginan yang mempertimbangkan berbagai aspek-aspek dalam mendesain dapat terwadahi melalui pemikiran-pemikiran praktisi yang sederhana dan mudah dimengerti oleh masyarakat dalam mendesain rumah tinggal layak huni berdasarkan kondisi sosial budayanya masing-masing.

\section{TINJAUAN PUSTAKA}

\section{Metode desain}

Fase proses desain dibagi dua tipe metode desain, yakni tipe Tradisional dan Rasional. Metode Desain Blackbox (Tradisional); metode desain blackbox ini, dilakukan secara spontanitas oleh desainer suatu karya. Ide datang bisa dari mana saja dan kapan saja untuk membuat suatu karya. Beberapa ciri-ciri metode blackbox menurut Jones (1970) adalah: ide kreatifitas rancangan tidak jelas datang dari mana konsepnya, sukar untuk menjelaskan konsep yang didapat, proses kreatif satu rancangan tidak dapat terlihat jelas, hasil suatu karya tidak dapat di-kritik, dan kapasitas produksi yang bergantung kepada ketersediaan waktu, mood, dan imajinasi si perancang.

Metode Desain Glassbox (Rasional), metode desain glassbox ini, dilakukan secara rasional dan logis oleh desainer terhadap karya yang dibuat, konsep desain yang dibuat tidak datang secara spontan, analisa dalam merancang dilakukan dengan lengkap, melalui proses pengujian, desain memiliki makna dan logis, strategi ditentukan dengan sangat matang.

Dalam metode desain rasional, desainer/ arsitek tidak selalu melakukan pembangunan terhadap karya mereka, namun karya yang mereka buat, juga dapat dibangun oleh orang lain. Berbeda dengan metode desain dengan metode tradisional bahwasanya desainer adalah pelaku pembangunannya.

Proses desain menurut (Lesau, 1986) dalam bukunya Berfikir Gambar bagi Arsitek dan Perancang dijelaskan bahwa proses desain dapat dilakukan oleh individu (semua proses dilakukan sendiri), regu (terdiri dari beberapa orang yang memiliki tugas masing-masing) dan masyarakat (proses desain

PAWON: Jurnal Arsitektur, Nomor 01 Volume IV, Januari-Juni 2020, ISSN 2597-7636 
dengan melibatkan partisipasi masyarakat), sedangkan untuk metode desain ditempuh dalam 5 langkah desain yaitu, merumuskan persoalan/ programing, membuat alternative, menilai, memilih, dan komunikasi (produk gambar).

Proses desain menurut (White, 1990) dalam bukunya Buku Sumber Konsep dijelaskan bahwa proses desain dilakukan dalam beberapa tahap berikut ini; tahap penyusunan program, rancangan skematik, pengembangan rancangan, dokumen kontrak, dan administrasi pelaksanaan. Hal-hal yang perlu diperhatikan dalam proses perencanaan dan perancangan adalah kebutuhan, rangkaian waktu, lingkungan yang diinginkan, hubungan antara masing-masing kegiatan, karakteristik, orang yang terlibat, kapasitas, kemudahan sirkulasi, pencahayaan dan tampilan bentuk.

Self enclosed modernity "modernism" Tadao Ando, dilakukan secara bersamaan dan berkesinambungan yang diawali dari menghubungkan ruang dalam dan ruang luar untuk menciptakan pengalaman ruang melalui material dan unsur alami seperti cahaya dan air sambil mencari bentuk sederhana yang cocok untuk mewujudkan keinginannya. Semua aspek dipikirkan secara bersamaan, (Setyowati, 2009).

Form follow function "Modern architecture" Louis Sullivan, dilakukan secara berurutan dan terstruktur mulai dari penyusunan program, analisis, konsep hingga muncul bentuk yang sesuai dengan fungsi dari ruang yang diakomodasi. Bentuk tidak menjadi hal yang penting dalam teori ini, bentuk cukup ditampilkan dalam wujud yang sederhana kubisme, (Loho, Poluan, dan Egam, 2015).

Feminisme architecture "Post Modern architecture" Zaha Hadid, teori ini juga dilakukan secara terstruktur dan berurutan tetapi lebih ditekankan dan dimulai dari studi transformasi bentuk terlebih dahulu. Studi bentuk dapat dicapai melalui metode studi maket, studi bentuk dengan lipatan kertas, ataupun dengan bantuan software 3D untuk mendapatkan sebuah bentukan, bentuk ini kemudian disesuaikan dengan kondisi tapak serta ruang dan strukturnya yang mengikuti bentuk, (Silaban, Punuh, 2011).

\section{Aspek desain}

Proses desain arsitektur perlu memperhatikan beberapa aspek yang berpengaruh terhadap perencanaan dan perancangan suatu desain arsitektural. Adapun aspek yang perlu diperhatikan dalam suatu proses desain antara lain, (Ratodi, 2014):

1. Aspek pengguna

Aktivitas, Perilaku, Fungsi, Organisasi, Tata nilai/kepercayaan, Persepsi, dan Kapasitas

2. Aspek Fisik

Kualitas lokasi/lingkungan, Kondisi site, Bangunan/fasilitas yang ada, Pelingkup/cangkang bangunan, Struktur, Sistem bangunan 
Perlengkapan/perabot, Material bangunan dan finishing, Pendukung/servis, Pemanfaatan fasilitas Setting aktifitas, Sirkulasi, Aspek lingkungan, Pemanfaatan energi, Daya tahan dan fleksibilitas

3. Aspek Eksternal

Ketentuan legal, Topografi, Iklim, Ekologi, Ketersediaan sumberdaya, Pasokan energi dan biaya Ekonomi, Anggaran biaya, dan Waktu

\section{Rumah tinggal}

Secara fisik dan fungsinya, rumah merupakan tempat untuk berlindung dari cuaca dan kondisi lingkungan sekitar, rumah juga sebagai tempat menyatukan keluarga, meningkatkan tumbuh kembang manusia, dan juga menjadi bagian dari gaya hidup (Wicaksono 2009). Menurut Badan Standardisasi Nasional -Tata Cara Perencanaan Lingkungan Perumahan Di Perkotaan tahun 2004, rumah merupakan bangunan yang memiliki fungsi sebagai tempat tinggal atau hunian dan sebagai sarana pembinaan keluarga. Jadi rumah tinggal atau hunian merupakan sebuah bangunan yang berfungsi sebagai tempat untuk menikmati kehidupan yang layak dan nyaman, tempat untuk berlindung, berkumpul, dan menunjukkan status tingkatan dalam masyarakat. Dalam perencanaan rumah tinggal ada beberapa pertimbangan yang harus diperhatikan menurut (Amin dalam Simbolon, 2017) antara lain ; Jumlah penghuni, Kebutuhan Ruang, Fungsi Ruang, Kenyamanan, Keamanan, dan Nilai Estetika.

\section{METODE KEGIATAN}

Metode yang digunakan dalam penelitian ini, yaitu metode kualitatif, dengan teknik wawancara mendalam (deep interview) dan observasi lapangan dengan variable kajian penelitian, kemudian dianalisis melalui teoriteori berdasarkan variable-variabel yang telah ditentukan. Hasil dari analisis tersebut kemudian diuraikan kualitatif untuk mendapatkan sebuah kesimpulan akhir.

Variabel penelitian meliputi teori desain, "modernism" (proses desain dilakukan secara bersamaan dan berkesinambungan antara ruang, bentuk, dan ruang luar, form follow function (teori berarsitektur yang lebih mementingkan efektifitas dan efisiensi ruang dan sirkulasi pergerakan) dan function follow form (teori desain yang lebih mementingkan proses mencari sebuah bentuk terlebih dahulu). Proses desain (untuk mengetahui tahapan proses desain oleh arsitek dalam mendesain), dan metode desain yang terdiri dari Metode Desain Blackbox (Tradisional) ide muncul secara spontan dan cara berfikirnya tidak terstruktur dan Metode Desain Glassbox (Rasional) ideide desain diwujudkan secara rasional, logis dan bertahap. Aspek-aspek 
desain (untuk mengetahui aspek-aspek apa saja yang menjadi pertimbangan utama oleh arsitek dalam mendesain rumah).

\section{HASIL DAN PEMBAHASAN \\ Objek penelitian}

Objek penelitian merupakan rumah tinggal yang merupakan hasil karya penghuni/arsitek itu sendiri. Berikut ini objek penelitian sementara yang akan diteliti, jumlah objek penelitian dapat bertambah berdasarkan kriteria dan informasi yang didapatkan dari daftar objek penelitian sementara sesuai teknik snowball sampling (Tabel 1).

Tabel 1.

Objek Penelitian

\begin{tabular}{|c|c|c|c|}
\hline No & Arsitek & Rumah Tinggal & Alamat \\
\hline 1. & $\begin{array}{l}\text { Objek } 1 \\
\text { Didik } \\
\text { Suharjanto }\end{array}$ & & Jl. Simpang Pandam Arum Malang \\
\hline 2. & $\begin{array}{l}\text { Objek } 2 \\
\text { Ahmad Fatah } \\
\text { Yasih }\end{array}$ & & $\begin{array}{l}\text { Perum Nadia Residence Jl. Ir. } \\
\text { Sukarno Dadaprejo Junrejo Kota } \\
\text { Batu }\end{array}$ \\
\hline 3. & $\begin{array}{l}\text { Objek } 3 \\
\text { Antung Haruji }\end{array}$ & & Jl. Papa Ungu \\
\hline
\end{tabular}

Objek 4

4. Suryo Tri

Harjanto

Syamsudin

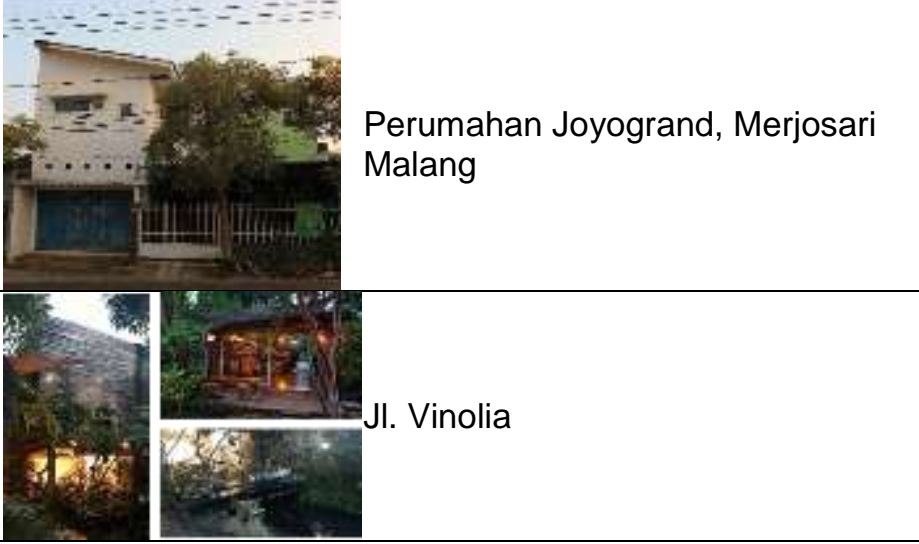

PAWON: Jurnal Arsitektur, Nomor -- Volume --, Bulan Tahun, ISSN 2597-7636 
Objek 6

6. Bayu Teguh Ujianto

Objek 7

7. Bayu

Sishandoko

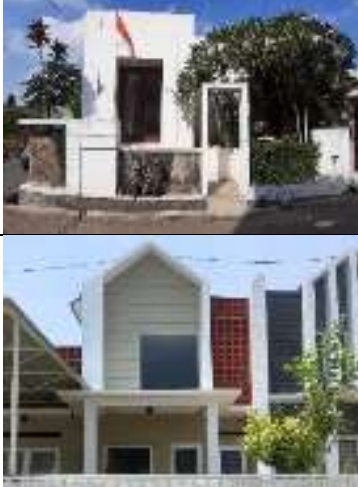

Jl. Sidomakmur Sengkaling

Perum Wijaya Kusuma Kepuharjo

\section{Penerapan aspek desain}

Hasil wawancara menunjukkan bahwa masing-masing arsitek memiliki persamaan dan perbedaan dalam dalam segi aspek mendesain rumah, terkait dengan aspek desain yang menjadi pertimbangan utama dalam melakukan proses analisis untuk mencapai sebuah konsep rancangan. Berikut ini aspek yang desain yang dipertimbangkan oleh masing-masing objek penelitian, Tabel 2.

Tabel 2.

Aspek desain

\begin{tabular}{|c|c|c|c|c|c|c|c|}
\hline \multirow{2}{*}{$\begin{array}{l}\text { Variabel Penelitian } \\
\text { Aspek desain }\end{array}$} & \multicolumn{7}{|c|}{ Objek Penelitian } \\
\hline & $\begin{array}{c}\text { Objek } \\
1\end{array}$ & $\begin{array}{l}\text { Objek } \\
2\end{array}$ & $\begin{array}{c}\text { Objek } \\
3\end{array}$ & $\begin{array}{c}\text { Objek } \\
4\end{array}$ & $\begin{array}{l}\text { Objek } \\
5\end{array}$ & $\begin{array}{l}\text { Objek } \\
6\end{array}$ & $\begin{array}{c}\text { Objek } \\
7\end{array}$ \\
\hline \multicolumn{8}{|l|}{ Aspek Pengguna } \\
\hline Aktifitas & $\sqrt{ }$ & $\sqrt{ }$ & $\sqrt{ }$ & $\sqrt{ }$ & $\sqrt{ }$ & $\sqrt{ }$ & $\sqrt{ }$ \\
\hline Perilaku & $\sqrt{ }$ & $\sqrt{ }$ & $\sqrt{ }$ & $\sqrt{ }$ & $\sqrt{ }$ & $\sqrt{ }$ & $\sqrt{ }$ \\
\hline Fungsi & $\sqrt{ }$ & $\sqrt{ }$ & $\sqrt{ }$ & $\sqrt{ }$ & $\sqrt{ }$ & $\sqrt{ }$ & $\sqrt{ }$ \\
\hline Kapasitas & $\sqrt{ }$ & $\sqrt{ }$ & $\sqrt{ }$ & $\sqrt{ }$ & $\sqrt{ }$ & $\sqrt{ }$ & $\sqrt{ }$ \\
\hline Tema/ langgam & & $\sqrt{ }$ & $\sqrt{ }$ & & $\sqrt{ }$ & & \\
\hline $\begin{array}{r}\text { Tata nilai/ } \\
\text { kepercayaan }\end{array}$ & & $\sqrt{ }$ & $\sqrt{ }$ & & & $\sqrt{ }$ & \\
\hline Sosial budaya & & $\sqrt{ }$ & $\sqrt{ }$ & & & & \\
\hline Biaya & $\sqrt{ }$ & $\sqrt{ }$ & $\sqrt{ }$ & $\sqrt{ }$ & $\sqrt{ }$ & $\sqrt{ }$ & $\sqrt{ }$ \\
\hline \multicolumn{8}{|l|}{ Aspek Fisik } \\
\hline Lingkungan & $\sqrt{ }$ & 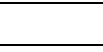 & 1 & & $\sqrt{ }$ & $\sqrt{ }$ & \\
\hline $\begin{array}{l}\text { Eksisting site dan } \\
\text { bangunan sekitar }\end{array}$ & $\sqrt{ }$ & $\sqrt{ }$ & $\sqrt{ }$ & $\sqrt{ }$ & $\sqrt{ }$ & $\sqrt{ }$ & $\sqrt{ }$ \\
\hline $\begin{array}{r}\text { Langgam fasade } \\
\text { bangunan }\end{array}$ & & $\sqrt{ }$ & & $\sqrt{ }$ & $\sqrt{ }$ & & \\
\hline Sistem bangunan & $\sqrt{ }$ & & & & $\sqrt{ }$ & & \\
\hline Struktur & $\sqrt{ }$ & $\sqrt{ }$ & $\sqrt{ }$ & & $\sqrt{ }$ & $\sqrt{ }$ & $\sqrt{ }$ \\
\hline Material & $\sqrt{ }$ & $\sqrt{ }$ & & & $\sqrt{ }$ & $\sqrt{ }$ & $\sqrt{ }$ \\
\hline Perabot & & & $\sqrt{ }$ & & $\sqrt{1}$ & & \\
\hline
\end{tabular}

PAWON: Jurnal Arsitektur, Nomor 01 Volume IV, Januari-Juni 2020, ISSN 2597-7636 


\begin{tabular}{|c|c|c|c|c|c|c|c|}
\hline Sirkulasi & $\sqrt{ }$ & $\sqrt{ }$ & $\sqrt{ }$ & $\sqrt{ }$ & $\sqrt{ }$ & $\sqrt{ }$ & $\sqrt{ }$ \\
\hline Setting aktifitas & $\sqrt{ }$ & $\sqrt{ }$ & $\sqrt{ }$ & & $\sqrt{ }$ & $\sqrt{ }$ & \\
\hline Pemanfaatan energi & & & & & $\sqrt{ }$ & & \\
\hline Daya tahan metarial & & $\sqrt{ }$ & & & $\sqrt{ }$ & & \\
\hline $\begin{array}{r}\text { Sistem pencahayaan } \\
\text { dan penghawaan }\end{array}$ & $\sqrt{ }$ & $\sqrt{ }$ & $\sqrt{ }$ & $\sqrt{ }$ & $\sqrt{ }$ & $\sqrt{ }$ & $\sqrt{ }$ \\
\hline \multicolumn{8}{|l|}{ Aspek eksternal } \\
\hline Topografi & $\sqrt{ }$ & & $\sqrt{ }$ & & & $\sqrt{ }$ & \\
\hline $\begin{array}{r}\text { Iklim (hujan, panas, } \\
\text { pencahayaan dan } \\
\text { penghawaan) }\end{array}$ & $\sqrt{ }$ & $\sqrt{ }$ & $\sqrt{ }$ & $\sqrt{ }$ & $\sqrt{ }$ & & $\sqrt{ }$ \\
\hline Ekologi & & & & & $\sqrt{ }$ & & \\
\hline Sumberdaya material & $\sqrt{ }$ & $\sqrt{ }$ & $\sqrt{ }$ & $\sqrt{ }$ & $\sqrt{ }$ & $\sqrt{ }$ & $\sqrt{ }$ \\
\hline Sumberdaya tukang & $\sqrt{ }$ & $\sqrt{ }$ & & & $\sqrt{ }$ & $\sqrt{ }$ & $\sqrt{ }$ \\
\hline Waktu & $\sqrt{ }$ & $\sqrt{ }$ & $\sqrt{ }$ & $\sqrt{ }$ & $\sqrt{ }$ & $\sqrt{ }$ & $\sqrt{ }$ \\
\hline
\end{tabular}

Keseluruhan arsitek dari segi aspek pengguna dalam mendesain rumah tinggalnya memiliki kesamaan pertimbangan yaitu mempertimbangkan aktifitas, perilaku, fungsi dan kapasitas serta biaya, namun hanya beberapa diantaranya yang mempertimbangkan aspek social budaya, kepercayaan dan langgam. Dari segi aspek fisik hasilnya lebih bervariasi, sedangkan dari segi aspek eksternal menunjukkan hasil yang kurang lebih sama dari keseluruhan arsitek.

Objek 1, aspek utama yang dipertimbangkan adalah terkait topografi site yang berkontur, sehingga beberapa ruang dibuat dengan system split level. Selain itu, faktor pemanfaatan pencahayaan dan penghawaan alami juga menjadi pertimbangan utama. Objek 2, aspek utama yang dipertimbangkan adalah mengenai biaya, sehingga rumah ini didesain sebagai rumah tumbuh, dan pemanfaatan material bekas menjadi yang utama. Selain itu, aspek sosial budaya dan kepercayaan juga banyak diterapkan dalam desain objek 2 ini. Objek 3, aspek utama yang menjadi pertimbangan adalah terkait dengan tata letak ruang yang terkait dengan aturan-aturan budaya dan ornamen jawa, serta aspek pertimbangan topografi lahan yang berkontur. Objek 4, rumah ini awalnya merupakan rumah berlantai 1 yang kemudian direnovasi menjadi 2 lantai, aspek desain utama pada rumah ini adalah terkait dengan pencahayaan dan penghawaan serta fasade yang menampilkan metafora sepasang wajah dari pemilik rumah. Objek 5, rumah ini juga memiliki konsep rumah tumbuh, aspek lingkungan ekologi dan penggunaan material bekas menjadi perhatian utama dalam desain. Objek 6, rumah ini juga didesain dengan konsep rumah tumbuh, yang penataan ruangnya diatur secara modular untuk mendapatkan efektifitas ruang pada lahan yang terbatas, hadirnya void/ open space pada bagian tengah rumah dimaksudkan untuk memanfaatkan pencahayaan dan penghawaan alami, nilai filoso jawa terkait pawon juga diterapkan sebagai ruang bersama. Objek 7 , desain yang menjadi pertimbangan utama adalah terkait dengan biaya,

PAWON: Jurnal Arsitektur, Nomor -- Volume --, Bulan Tahun, ISSN 2597-7636 
sehingga banyak penggunaan material yang murah dan penggunaan perabot yang didesain dan dibuat sendiri.

\section{Penerapan Metode Desain}

Berdasarkan pada hasil identifikasi dan analisis objek penelitian maka berikut ini hasil penerapan teori desain pada masing-masing objek sebagai berikut:

Tabel 3.

Penerapan metode desain

\begin{tabular}{|c|c|c|}
\hline $\begin{array}{c}\text { NO } \\
.\end{array}$ & $\begin{array}{c}\text { Objek/Arsit } \\
\text { ek }\end{array}$ & Penerapan desain \\
\hline 1 & $\begin{array}{l}\text { Objek } 1 \\
\text { (Didik } \\
\text { Suharjanto) }\end{array}$ & $\begin{array}{l}\text { Dalam mendesain dimulai dari fungsi dan aktifitas ruang } \\
\text { terlebih dahulu, yaitu kamar tidur, kamar mandi dan seterusnya, } \\
\text { sehingga bentuknya mengikuti fungsi. Prosesnya melalui } \\
\text { analisis-analisis terkait dengan tapak, pencahayaan dan } \\
\text { penghawaan, hingga ditemukan konsep menuju pada } \\
\text { pengembangan desain. }\end{array}$ \\
\hline 2 & $\begin{array}{l}\text { Objek } 2 \\
\text { (Afys) }\end{array}$ & $\begin{array}{l}\text { Objek } 2 \text { juga didesain berdasarkan fungsi dan aktifitas serta } \\
\text { kemudahan sirkulasi, sehingga bentuk rumah mengikuti fungsi } \\
\text { ruang. Proses diawali dengan analisis kebutuhan ruang, } \\
\text { skematik desain berupa sketsa-sketsa ide, dan masuk pada } \\
\text { tahap pengembangan desain serta pembuatan gambar kerja. } \\
\text { Dalam proses pembangun terdapat perubahan-perubahan } \\
\text { desain karena faktor teknis dan juga ketersediaan barang } \\
\text { bekas yang dimiliki, sebagaimana barang bekas menjadi focus } \\
\text { utama material yang digunakan dalam desain. }\end{array}$ \\
\hline 3 & $\begin{array}{l}\text { Objek } 3 \\
\text { (Antung } \\
\text { Harudji) }\end{array}$ & $\begin{array}{l}\text { Penataan ruang menjadi penting pada desain objek } 3 \text { ini. } \\
\text { Penataan ruang harus benar benar ditata, karena mengikuti } \\
\text { konsep orang Jawa, banyak aturan aturan dalam mendesain } \\
\text { rumah dari kebutuhan ruangnya, seperti orientasi dan tata letak } \\
\text { kamar/ kamar mandi. Bentuk atau tampilan rumah juga } \\
\text { mengikuti tata ruang. Prosesnya tetap diawali dari proses } \\
\text { analisis, konsep dan tahan pengembangan desain. }\end{array}$ \\
\hline 4 & $\begin{array}{l}\text { Objek } 4 \\
\text { (Suryo Tri } \\
\text { Harjanto) }\end{array}$ & $\begin{array}{l}\text { Fungsi dan hirarki ruang pada objek } 4 \text { ini menjadi sangat } \\
\text { penting. Ide fasade yang ingin menghadirkan metafora dari } \\
\text { sepasang wajah pemilik memberikan pengaruh pada tata letak } \\
\text { ruang dilantai } 2 \text {. Secara keseluruhan, desain rumah ini lebih } \\
\text { mengutamakan fungsi dan tata letak ruang, namun memiliki ide } \\
\text { terkait dengan tampilan bukan pada ide bentuk secara } \\
\text { keseluruhan. Prosesnya juga dilakukan secara terstruktur mulai } \\
\text { dari proses analisis, konsep dan tahap pengembangan desain. }\end{array}$ \\
\hline 5 & $\begin{array}{l}\text { Objek } 5 \\
\text { (Agus } \\
\text { Samsudin) }\end{array}$ & $\begin{array}{l}\text { Konsep rumah ini diawali dari konsep tata letak massa terlebih } \\
\text { dahulu kemudian dilakukan penataan ruang berdasarkan } \\
\text { fungsi masing-masing massa bangunan. Sehingga desain } \\
\text { rumah ini, berfikirnya dari bentuk dan penataan massa terlebih }\end{array}$ \\
\hline
\end{tabular}

PAWON: Jurnal Arsitektur, Nomor 01 Volume IV, Januari-Juni 2020, ISSN 2597-7636 


\begin{tabular}{|c|c|c|}
\hline & & $\begin{array}{l}\text { dahulu kemudian penataan fungsi ruang secara horizontal } \\
\text { maupun vertical. Ide-ide terkait detail arsitektural sering muncul } \\
\text { secara spontan, proses desain pun dilakukan secaratidak } \\
\text { terstruktur, produk dibuat hanya dalam bentuk sketsa-sketsa } \\
\text { ide tanpa dilakukan tahap pengembangan desain. Sehingga } \\
\text { sering terjadi perubahan-perubahan konsep desain yang } \\
\text { tergantung pada ide spontan dan factor teknis dilapangan. }\end{array}$ \\
\hline 6 & $\begin{array}{l}\text { Objek } 6 \\
\text { (Bayu } \\
\text { Teguh) }\end{array}$ & $\begin{array}{l}\text { Objek } 6 \text {, metode yang digunakan dalam desain objek } 6 \text { ini } \\
\text { adalah mengutamakan penataan ruang secara modular untuk } \\
\text { mendapatkan ruang efektif pada lahan yang terbatas serta } \\
\text { kemudahan modul struktur. Sehingga fungsi dan aktifitas } \\
\text { menjadi sangat penting, dan bentuk atau tampilan mengikuti } \\
\text { ruang. Proses desain dilakukan secara utuh mulai analisis } \\
\text { kebutuhan ruang, konsep, dan pengembangan desain. Namun, } \\
\text { dalam proses pelaksanaan terdapat penyesuaian-penyesuaian } \\
\text { sesuai dengan perkembangan atau ide-ide yang muncul } \\
\text { secara spontan. }\end{array}$ \\
\hline 7 & $\begin{array}{l}\text { Objek } 7 \\
\text { (Bayu } \\
\text { Sishandoko) }\end{array}$ & $\begin{array}{l}\text { Desain rumah objek } 7 \text { ini juga menerapkan metode bentuk } \\
\text { mengikuti fungsi, proses desain juga dilakukan secara } \\
\text { terstruktur, mulai dari proses analisis, konsep dan } \\
\text { pengembangan desain yang disesuaikan dengan kondisi biaya } \\
\text { yang dimiliki. }\end{array}$ \\
\hline
\end{tabular}

Metode desain yang banyak digunakan oleh arsitek yang dijadikan objek penelitian, secara umum cara berarsitektur dimulai dari fungsi dan penataan ruang terlebih dahulu berdasarkan kebutuhan dan aktifitas. Berikut ini gambaran denah masing-masing objek penelitian, Gambar 1.

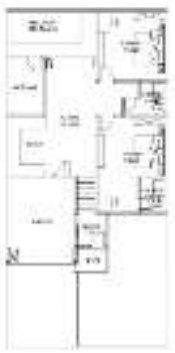

Objek 1

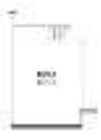

Objek 3

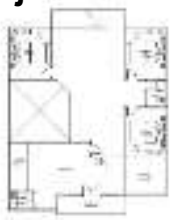

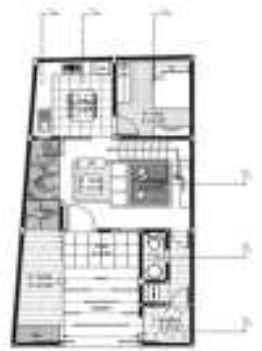

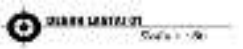

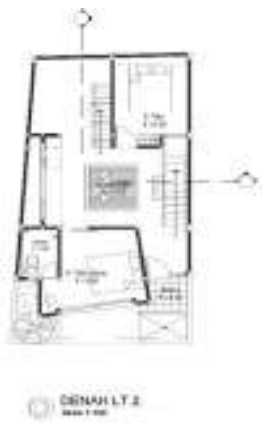

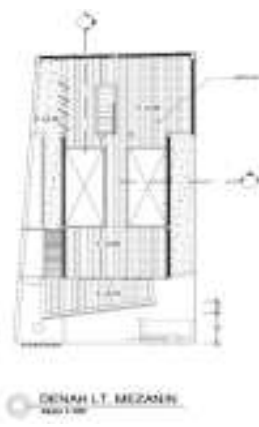

Objek 2

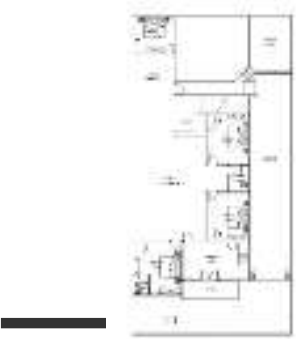

Objek 4
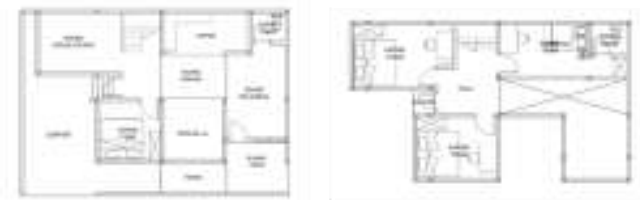

PAWUN: Jurnal Arsitektur, Nomor -- Volume --, Bulan Tahun, ISSN 2597-7636 


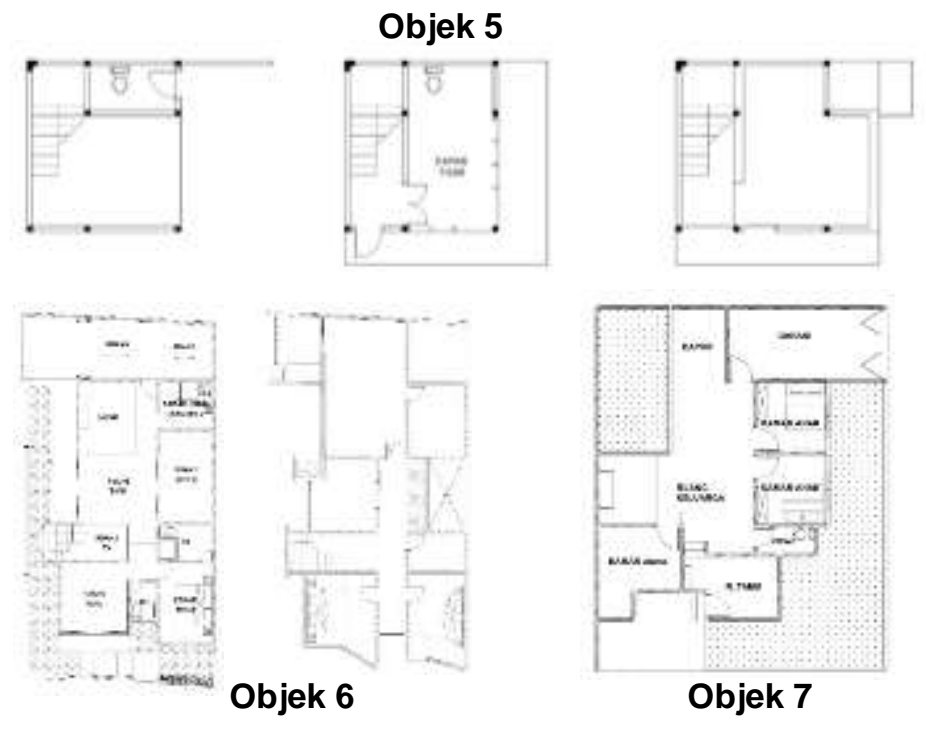

Gambar. 1.

Hasil desain denah objek penelitian

Sumber: Survey lapangan, 2019

\section{KESIMPULAN}

Secara keseluruhan dari semua objek penelitian ditemukan bahwa teori desain yang digunakan menggunakan teori form follow function yaitu mengutamakan fungsi ruang terlebih dahulu kemudian bentuk mengikuti fungsi. Hanya objek nomer 5 yang diawali dari tata letak massa bentuk terlebih dahulu kemudian dilakukan zoning tata letak ruang di masing-masing massa yang ada. Dari segi proses desain, secara umum dilakukan dengan metode glass box (rasional) yaitu dilakukan secara keseluruhan diawal mulai dari analisis, konsep/ skematik desain, dan tahap pengembangan desain, kecuali objek 5 yang dilakukan secara spontan atau black box (tradisional) yakni segala sesuatunya dilakukan secara spontan sesuai dengan kebutuhan atau prioritas pada saat itu. Meskipun proses secara keseluruhan objek dilakukan dengan metode glass box, namun dalam proses pembangunannya sering terjadi perubahan-perubahan secara spontan karena factor-faktor teknis atau eksternal lainnya yang mengakibatkan desain harus berubah dari yang direncanakan sebelumnya. Hal itu sesuatu hal yang wajar, karena pengaruh dari aspek-aspek tertentu yaitu pengguna, fisik, dan eksternal. 


\section{DAFTAR PUSTAKA}

Badan Standardisasi Nasional, 2004 Tata Cara Perencanaan Lingkungan Perumahan di Perkotaan.

Jones, JC, 1990. Developments in Design Methodology, New York, John Wiley \& sons Ltd

Lesau, Paul, 1986. Berfikir Gambar bagi Arsitek dan Perancang. ITB: Bandung

Simbolon, Nasution,2017. Desain Rumah Tinggal Yang Ramah Lingkungan Untuk Iklim Tropis, Jurnal Education Buuilding,Volume 3, Nomor 1, Juni 2017: 46-59, ISSN-E : 2477-4901, ISSN-P : 2477-4898

Setyowati, Wiwit, 2009. Teori, Metoda, dan Aplikasi Karya Arsitektur Tadao Ando. Jurnal Teknik Sipil dan Perencanaan. Nomor 1 Volume 11Januari 2009. Hal: 81-92

Sugiyono, 2010. Memahami Penelitian Kualitatif. Alfabeta: Bandung

Silaban, Punuh, 2011. Arsitektur Feminisme. MEDIA MATRASAIN VOL 8 NO 2 AGUSTUS 2011, Hal: 29-39

Windi D. Loho, Roosje J. Poluan, Pingkan P. Egam, 2015. GEDUNG KONVENSI DI TOMOHON (Optimalisasi Form Follow Function oleh Louis Sullivan). Jurnal Arsitektur DASENG UNSRAT Manado. Vol 4, No 2 (2015), Hal: 170-177

White, T. Edward. 1990. Buku Sumber Konsep- sebuah kosakata bentukbentuk arsitektural. Intermata: Bandung

Wicaksono, A. A. (2009). Menciptakan Rumah Sehat. Jakarta: Griya Kreasi. 